\title{
Yield and Phytochemical Compounds of Broccoli as Affected by Temperature, Irrigation, and Foliar Sulfur Supplementation
}

\author{
Zoltán Pék ${ }^{1}$ \\ Institute of Horticultural Technology, Szent István University, Páter K. ut 1., \\ H-2103 Gödöllö, Hungary
}

Hussein Daood, Magdolna Gasztonyi Nagyné, Mária Berki,
and Marianna Márkus Tóthné
Central Food Research Institute Herman O. st. 15. H-1022 Budapest,
Hungary

András Neményi and Lajos Helyes

Institute of Horticultural Technology, Szent István University, Páter K. ut 1., H-2103 Gödöllö, Hungary

Additional index words. Brassica oleracea convar. botrytis var. italica, phenolics, sulforaphane, TEAC, irrigation

\begin{abstract}
Two experiments were carried out in 2010 to determine how cultivation period/ harvest season, plant water status/irrigated, or rainfed and foliar sulfur supplementation influences the yield, sulforaphane, phenolics content, and polyphenol composition of broccoli cultivar Parthenon. Yield was significantly higher in the fall harvests. Foliar sulfur treatment induced earliness in irrigated broccoli in the fall harvest season of main florets by $44 \%$. Sulforaphane content was higher in the fall harvests regardless of treatments. Harvest season also influenced total polyphenol content with the highest values measured in the spring season. Sulfur treatment in combination with irrigation increased total polyphenol content by $24 \%$ in spring and this change was statistically significant. Harvest season also affected trolox equivalent antioxidant capacity (TEAC) values with the highest values $\left(4.3 \mathrm{mmol} \cdot \mathrm{kg}^{-1}\right)$ also measured in spring. In the irrigated treatment alone or irrigated treatment combined with sulfur treatment, spring season values were higher by $24 \%$ and $11 \%$, respectively, compared with fall values and the difference between treatments was significant. Caffeic acid glucoside was one of the major phenolic components in both spring and fall season harvests, whereas ferulic acid glucoside could only be detected in spring florets. From the measured phenolic components, gallic acid content was the only one that was significantly raised by foliar sulfur supplementation in both spring and fall harvests in irrigated or rainfed treatments. Maximum gallic acid values $\left(7.1\right.$ to $\left.7.2 \mathrm{mg} \cdot \mathrm{kg}^{-1}\right)$ occurred in the irrigated combined with foliar sulfur treatment of the fall harvest in side and main florets, respectively. The season, irrigation, and foliar sulfur supplementation were related changes in other phenolic component contents and are also described in detail.
\end{abstract}

Glucosinolate is the main phytochemical found in cole crops. There has been a growing research interest in the bioactive compounds of broccoli (Brassica oleracea L.) and their implications in human health and plant protection with regard to the influence of biotic and abiotic factors (Jahangir et al., 2009; Jeffery et al., 2003). This interest can be explained by data suggesting the importance of the dietary constituents of broccoli in the prevention and therapy of cancer, which has been recently

Received for publication 2 July 2012. Accepted for publication 28 Sept. 2012.

This study was partially funded by the TÁMOP4.2.1.B-11/2/KMR-2011-0003 project.

${ }^{1}$ To whom reprint requests should be addressed; e-mail pek.zoltan@mkk.szie.hu. enzymes. Also Anupama et al. (2008) have reported that ethanol extract of broccoli flower heads possesses an antimutagenic property.

Phenolic compounds, besides glucosinolates of broccoli florets, also possess antioxidant and anticarcinogenic properties (Podsedek, 2007; Tomás-Barberán and Espín, 2001; Vallejo et al., 2002) if prepared by steaming, rather than other cooking processes (Cartea et al., 2011; Conaway et al., 2000).

The effect of broccoli genotype on glucosinolate and phenolic compound content and profile was investigated by several authors. Brown et al. (2002) observed 10-fold differences in glucoraphanin and total aliphatic glucosinolate levels of broccoli florets between the highest and lowest genotypes examined. They also found that the synthesis of aliphatic glucosinolates such as glucoraphanin was regulated primarily by genotype $(60 \%)$ with environmental $(5 \%)$ and environment $\times$ genotype $(10 \%)$ factors exerting less effect. On the other hand, indolyl glucosinolates such as glucobrassicin were less affected by genotype $(12 \%)$ and more by environment $(33 \%)$ and environment $\times$ genotype $(21 \%)$. Vallejo et al. (2002) also report significant differences in total glucosinolate, phenolic compounds, and vitamin $\mathrm{C}$ contents in 14 cultivars (genotypes) grown under uniform cultural conditions in Spain. Pérez-Balibrea et al. (2011) underline the findings of Brown et al. (2002) that aliphatic glucosinolates are more affected by genetic factors than indolic glucosinolates in the case of seeds and sprouts of three broccoli cultivars.

The effect of growing period (spring or fall) under field conditions on the glucosinolatemyrosinase system was examined by Charron et al. (2005a, 2005b) in Illinois. They showed that total glucosinolate concentrations at harvest had a negative linear but positive quadratic relationship with daylength and temperature during the 2 weeks preceding harvest and a positive linear but negative quadratic relationship with photon flux over the same 2 weeks. The regression model for indole glucosinolate concentrations similarly varied with mean daylength, temperature, and photon flux over the 4 weeks before harvest. Glucoraphanin concentrations at harvest decreased linearly with mean photon flux from transplanting to harvest and had a negative linear but positive quadratic relationship with daylength from transplanting to harvest (Charron et al., 2005a). Myrosinase activity on a fresh weight basis $\left(\mathrm{U} \cdot \mathrm{g}^{-1}\right)$ had a negative linear relationship with temperature and a positive linear but negative quadratic relationship with photon flux. Myrosinase activity on a protein basis $\left(\mathrm{U} \cdot \mathrm{mg}^{-1}\right)$ had a positive linear and a negative quadratic relationship with both temperature and photon flux (Charron et al., 2005b). The effect of solar radiation on the flavonol content in broccoli florets grown in spring and fall cultivation periods under field conditions was determined by Gliszczyńska-Świgło et al. (2007). Quercetin and kaempferol contents were highly positively correlated with total solar radiation from planting to harvest. 
The effect of poor $\left(15 \mathrm{~kg} \cdot \mathrm{ha}^{-1}\right)$ or rich $\left(150 \mathrm{~kg} \cdot \mathrm{ha}^{-1}\right)$ sulfur soil fertilization on health-promoting compounds, during inflorescence developmental stages, under field conditions, during the spring cultivation period, in three broccoli cultivars was measured by Vallejo et al. (2003a). Phenolic compounds and vitamin $\mathrm{C}$ content showed a rising trend regardless of sulfur fertilization, whereas significant differences were detected in the first two developmental stages in total glucosinolate content. With low sulfur fertilization, the highest glucosinolate concentration was measured in the second stage, whereas this was true for the third stage in the case of high sulfur fertilization (Vallejo et al., 2003a). The same sulfur soil fertilization rates during early or late spring field cultivation were carried out to investigate their effect of phenolic compounds and vitamin C (Vallejo et al., 2003b) and glucosinolate contents (Vallejo et al., 2003c) in inflorescences of eight broccoli cultivars in Spain. They observed no significant difference in total glucosinolate levels between rich and poor sulfur fertilization but a higher level was detected in the late spring cultivation period (Vallejo et al., 2003c). In the case of phenolic compounds and vitamin $\mathrm{C}$, the late spring cultivation period combined with rich sulfur fertilization gave the highest concentrations (Vallejo et al., 2003b).

There is no literature dealing with the effect of optimum or low soil water content on the bioactive components of broccoli under field conditions. Only under greenhouse conditions in Brazil, Cogo et al. (2011) reported that low soil water content during growth combined with post-harvest cold storage gave the best preservation of antioxidant activity and L-ascorbic acid content in broccoli florets, whereas phenolic compound content was independent of cultivation or post-harvest storage conditions.

The aim of the present study was to investigate the effect of foliar sulfur supplementation, irrigation, and different cultivation periods (spring/fall) on the bioactive constituents of broccoli florets of the same genotype grown under field conditions in Hungary.

\section{Materials and Methods}

Plant material and experimental design

Two experiments were carried out in 2010. Expt. 1 spring cultivation between April and June and Expt. 2 summer/fall cultivation between July and October. In both experiments, Parthenon $\mathrm{F}_{1}$ cultivar was used (Sakata Vegetables Europe S.A.S., 2012). In both experiments plants were planted out in rows with a plant density 6.25 plants $/ \mathrm{m}^{2}$. In Expt. 1, seeds were sown on 10 Mar. and seedlings were planted out in the field on 17 Apr. Harvesting dates were 24 and 28 June. In Expt. 2 seeds were sown on 20 June and seedlings were planted out in the field on 21 July. Harvesting dates were 30 Sept. and 7, 14, 21, and 28 Oct. In the case of Expt. 2, side florets were harvested during the last harvest date (28 Oct.). The experimental design was a randomized block $\left(40 \mathrm{~m}^{2}\right.$ per plot) with four replications for yield evaluation. We chose three florets in each replication for the analysis of phytochemicals.

There was an irrigation treatment (regularly irrigated with rainfed control). According to Helyes and Varga (1994), daily potential evapotranspiration of vegetable crops (tomato) is well estimated by expected daily average temperature divided by five expressed in millimeters. Calculation method for the amount of irrigation was based on weather forecast data. Temperature forecast of the Hungarian Meteorological Service (2010) for every next two 2- and 3-d intervals per week were used to calculate the daily potential evapotranspiration. The amount of irrigation was calculated by daily potential evapotranspiration for the forecasting period corrected by the amount of precipitation. If precipitation covered the irrigation demand until the next irrigation date, we did not irrigate, but if it was less than irrigation demand, we supplied the amount of daily potential evapotranspiration. Regularly irrigated plants were irrigated by calculated amount of water every Monday, Wednesday, and Friday morning from 21 July until 5 Oct. in fall, so 488 and $273 \mathrm{~mm}$ water was usable for plants in irrigated and rainfed plants, respectively (Fig. 2). Irrigation water was applied by drip irrigation, one lateral for every twin rows. The spacing between the emitters was $0.3 \mathrm{~m}$ with discharge rates of $4 \mathrm{~L} \cdot \mathrm{h}^{-1}$.

Irrigation was not applied in the case of Expt. 2, because the spring/summer cultivation period was abnormally rainy with precipitation over $43 \mathrm{~d}$ of $380 \mathrm{~mm}$ (Fig. 1). In

\section{Spring}

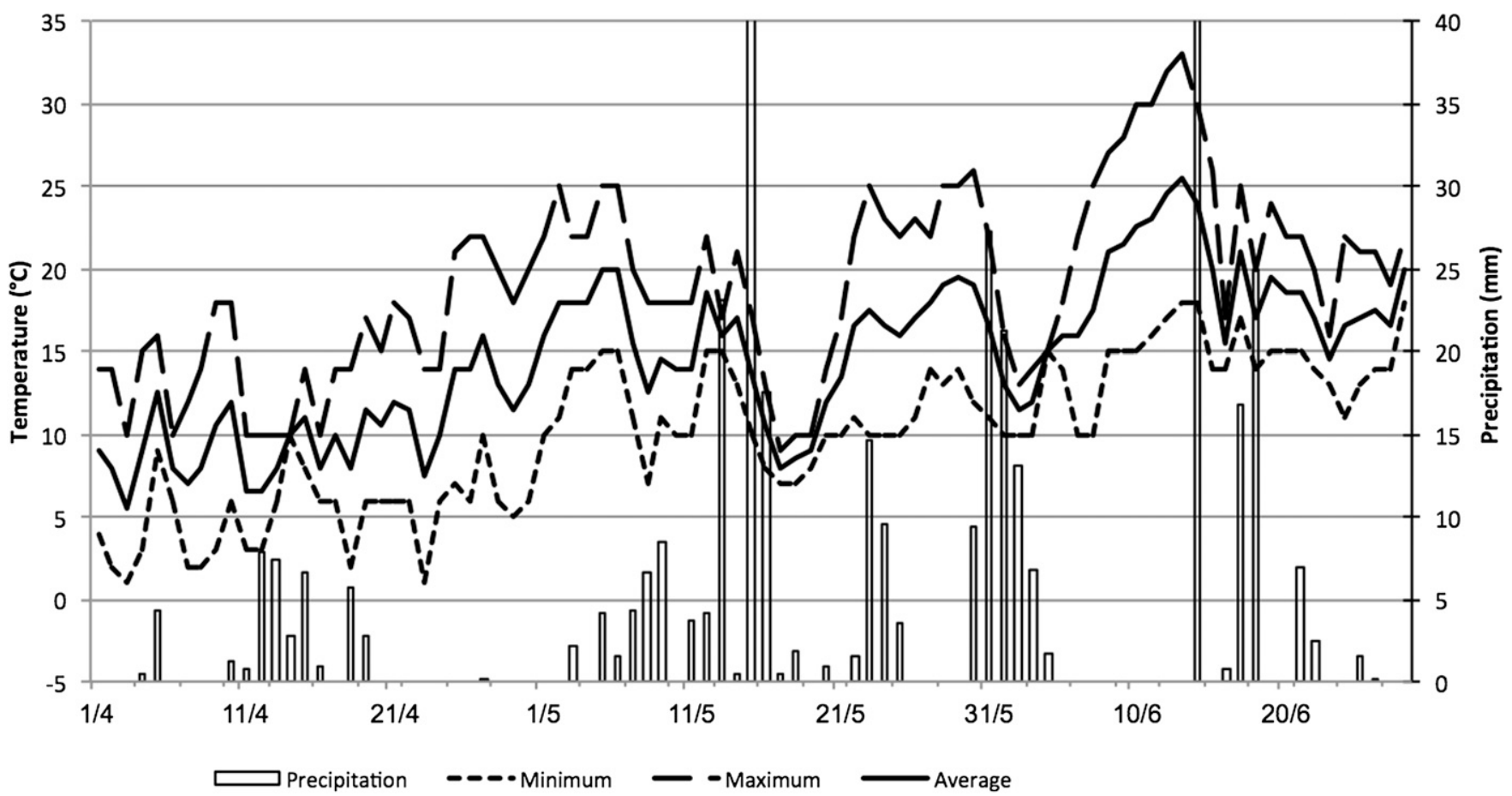

Fig. 1. Minimum, maximum, average daily temperature, and precipitation during spring broccoli season in 2010. 


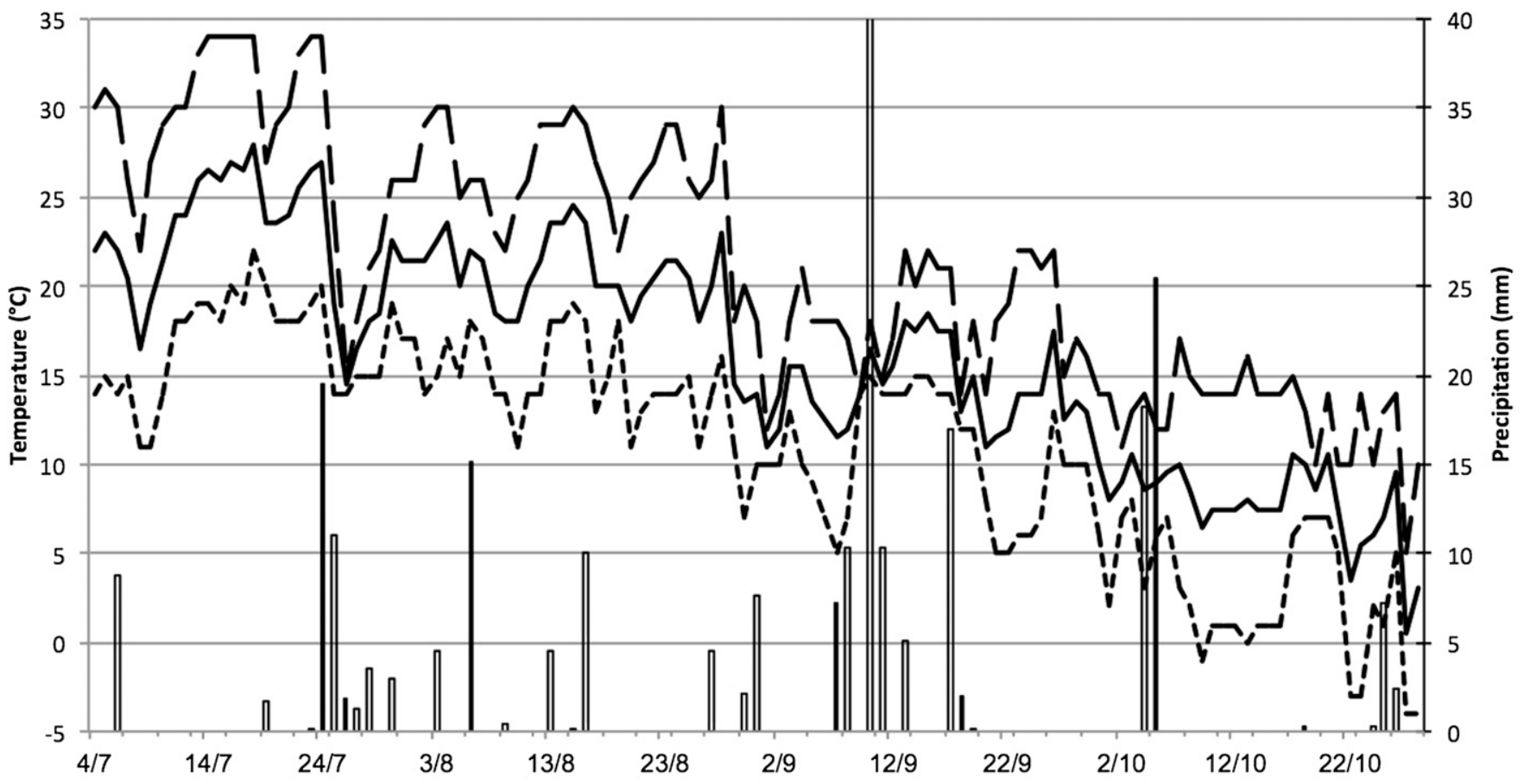

$\square$ Precipitation - - Minimum - Maximum - Average

Fig. 2. Minimum, maximum, average daily temperature, and precipitation during fall broccoli season in 2010.

both experiments foliar sulfur supplementation was started at the time of floret formation. In Expt. 1, foliar application of $0.4 \%$ sulfur (Amalgerol S; Cheminova Hungary Ltd.) was applied four times on 22 and 30 May and 6 and 12 June. In Expt. 2, foliar application was made eight times on 18 and 26 Aug., 2, 7, 15, 23, and 30 Sept., and 8 Oct.

\section{Measurement of environmental parameters}

Temperature and precipitation were measured six times per hour by a Campbell CR21X meteorological instrument (Campbell Scientific Inc., Loughborough, U.K.).

\section{Chemical analysis}

The conversion (hydrolysis) of the glucosinolate glucoraphanin to sulforaphane (4-methylsulfinylbutyl-isothiocyanate) was mediated by myrosinase located in plant tissues.

To release sulforaphane from glucoraphanin, the 1-g lyophilized broccoli sample was suspended in $20 \mathrm{~mL}$ of $0.1 \mathrm{M} \mathrm{HCl}$ shaken at $42{ }^{\circ} \mathrm{C}$ for $2 \mathrm{~h}$ (Nakagawa et al., 2006). Sulforaphane was extracted twice with $25 \mathrm{~mL}$ of dichloromethane. The solvent phases were pooled and dried over anhydrous $\mathrm{Na}_{2} \mathrm{SO}_{4}$. Then the extract was evaporated under vacuum at maximum $40{ }^{\circ} \mathrm{C}$. The residues were dissolved in $5 \mathrm{~mL}$ acetonitrile. To achieve complete solubility, the extract was ultrasonicated for $1 \mathrm{~min}$ in a water bath ultrasonic device (Tesla, Roznov, Czech. Republic).

Sulforaphane was determined by the modified reverse-phase high-performance liquid chromatography (HPLC) procedure of Liang et al. (2006) with modification. The compounds were separated with a Nucleosil-100$\mathrm{C} 18,3 \mu \mathrm{m}, 4.6 \mathrm{~mm} \times 250-\mathrm{mm}$ column with a gradient elution of A (distilled water) and $\mathrm{B}$ (acetonitrile) as follows: linear gradient from $70 \% \mathrm{~A} / 30 \% \mathrm{~B}$ to $25 \% \mathrm{AB} / 75 \% \mathrm{~B}$ in 0 to $10 \mathrm{~min}$, isocratic elution $25 \% \mathrm{~A} / 75 \% \mathrm{~B}$ 10 to $20 \mathrm{~min}$; gradient elution from $25 \%$ $\mathrm{A} / 75 \% \mathrm{~B}$ to $70 \% \mathrm{~A} / 30 \% \mathrm{~B}, 20$ to $22 \mathrm{~min}$; and isocratic elution $70 \% \mathrm{~A} / 30 \% \mathrm{~B}, 22$ to $25 \mathrm{~min}$. The flow rate was $0.7 \mathrm{~mL} \cdot \mathrm{min}^{-1}$. The sulforaphane was detected at $195 \mathrm{~nm}$. A Waters Alliance chromatograph consisting of a Model 2695 Separation Module and a Model 2996 photodiode-array detector was used. The chromatograph was operated by Empower software.

Peak of sulforaphane was identified by comparing retention time and spectral properties with those of standard material, which was used as external standard and cochromatographed for quantification.

Determination of phenols in broccoli by reverse-phase high-performance liquid chromatography

Sample preparation. The fresh broccoli florets and non-tough stems were pulped with a blender. Phenol components were extracted from $5.0-\mathrm{g}$ well-homogenized samples with $25 \mathrm{~mL} 2 \%$ acetic acid in methanol. After a 20 -min shaking $\left(160 \mathrm{rpm} \cdot \mathrm{min}^{-1}\right)$, the flasks were left at $4{ }^{\circ} \mathrm{C}$ overnight. The next day the samples were again shaken for $5 \mathrm{~min}$ and then filtered through filter paper. The residues were washed twice with $2.5 \mathrm{~mL}$ solvent. The filtrates were further cleaned by passing through a $0.45-\mu \mathrm{m}$ HPLC syringe filter before injection into a HPLC column for analysis of phenol compounds.

High-performance liquid chromatography analysis. A Waters Alliance system consisting of a Model 2695 separation module and a Model 2996 photodiode-array detector was used for the chromatographic analysis of broccoli phenols. The system was operated by Empower software. Chromatographic separation of phenols was performed on a EC NUCLEODUR Sphinx RP, $3 \mu \mathrm{m}, 150 \times 4.6$ analytical column using gradient elution. The gradient elution started with a linear gradient from $95 \% \mathrm{~A} / 5 \% \mathrm{~B}$ to $35 \% \mathrm{~A} / 65 \% \mathrm{~B}$ in 15 min; isocratic elution $35 \% \mathrm{~A} / 65 \% \mathrm{~B}$ up to $20 \mathrm{~min}$; gradient elution from $35 \% \mathrm{~A} / 65 \%$ $\mathrm{B}$ to $20 \% \mathrm{~A} / 80 \% \mathrm{~B}$ in $4 \mathrm{~min}$; isocratic elution $20 \% \mathrm{~A} / 80 \% \mathrm{~B}$ for $4 \mathrm{~min}$; and gradient elution from $20 \% \mathrm{~A} / 80 \%$ B to $95 \% \mathrm{~A} / 5 \% \mathrm{~B}$ in $4 \mathrm{~min}$. The injected volume was $20 \mu \mathrm{L}$ and a flow rate was $0.6 \mathrm{~mL} \cdot \mathrm{min}^{-1}$.

Peaks of phenol components were identified by comparing their spectral characteristics and retention with those of available standards. Some compounds were tentatively identified on the basis of their spectral characteristics as compared with literature data and retention behavior. For quantitative determination, the compounds were detected at their absorption maxima (280, 320, $355 \mathrm{~nm})$.

Calibration curves of the standard materials were prepared by plotting peak area and concentration of the working solutions of 
concentration between 0 and $100 \mu \mathrm{g} \cdot \mathrm{mL}^{-1}$ for each one. Phenols having absorption maxima $\approx 180 \mathrm{~nm}$ were quantified as gallic acidequivalent, whereas flavonoids were quantified as rutin-equivalent.

\section{Determination of total polyphenol content, antioxidant capacity, and nitrate.}

Chemicals. Chemicals were methanol (AnalaR Normapur), Folin-Ciocalteu reagent (Merck Darmstadt), zinc granules, 2,2-diphenyl-1-picrylhydrazyl (DPPH) (SigmaAldrich), Trolox purum (Fluka Buchs), 1-naphtylamine a.r., acetic acid $96 \%$ a.r., ammonia a.r., cadmium acetate a.r., $\mathrm{K}_{4}\left[\mathrm{Fe}(\mathrm{CN})_{6}\right] \cdot 3 \mathrm{H}_{2} \mathrm{O}$ a.r., potassium nitrate a.r., sodium carbonate a.r., sulfanilic acid purum, sample preparation for polyphenols, and free radical scavenging activity: $\mathrm{ZnSO}_{4} \cdot 7 \mathrm{H}_{2} \mathrm{O}$ a.r. (Reanal).

To exactly weighed $5 \mathrm{~g}$ of ground vegetables, $20 \mathrm{~mL}$ methanol was added. The mixture was refrigerated overnight, shaken for $20 \mathrm{~min}$, and filtered. Two parallel extractions were performed. This solution was used for the measurements of total polyphenol and free radical scavenging activity.

Measurement of total phenolics. Color reaction with Folin-Ciocalteu reagent was performed according to MSZ 9474-80 (1980) in an appropriate dilution. Total polyphenols are given as gallic acid equivalent $\left(\mathrm{mg} \cdot \mathrm{kg}^{-1}\right)$.

\section{Antioxidant activity (free radical scavenging activity)}

A slightly modified version of BrandWilliams et al.'s (1995) method was used. The DPPH stabile-free radical was reacted with the sample extract in a relevant dilution at $36{ }^{\circ} \mathrm{C}$ for $30 \mathrm{~min}$. The antioxidant activity is given in TEAC $\left(\mathrm{mmol} \cdot \mathrm{kg}^{-1}\right)$.

\section{Statistical analysis}

All samples were measured in three repetitions. The data were analyzed by twofactor analysis of variance with repetitions and the means separated using the Student's test at $P=0.05$.

\section{Results}

Yield. Precipitation in 2010 was extreme with the highest rainfall measured in the last century in Hungary. The distribution of this precipitation was very balanced and provided mostly optimal water supply for irrigated and unirrigated plants. Consequently no unirrigated treatment was achieved. Rainfall was less in the fall harvesting period, but the natural rainfall did not limit broccoli production. Table 1 shows harvested yield in the spring and fall seasons. Fall yield was significantly higher than in the spring. Irrigation alone increased yield $36 \%$ and in combination with sulfur treatment by $96 \%$ compared with control in the first fall harvest. In the last fall harvest, yield was increased by irrigation alone only by $4 \%$ and by $7 \%$ in combination with sulfur treatment compared with control, but total cumulative yield did not differ significantly among treatments (Fig. 3). Sulfur treatment resulted in higher total yield both in irrigated and unirrigated plants, but it was not significant. When comparing earliness of fall-harvested main rosettes, sulfur treatment induced earliness in irrigated broccoli at the first harvest date by $44 \%$ and this difference was significant (Fig. 3).

Sulforaphane. The average sulforaphane content in the two experiments varied between 9.9 and $99.9 \mathrm{mg} \cdot \mathrm{kg}^{-1}$ (in fresh weight) depending on the cultivation period and the treatments (Table 2). During the spring cultivation period there was $380 \mathrm{~mm}$ precipitation; thus, there was no water deficit in the unirrigated treatments. Under optimal water supply, the sulfur treatment (foliar application) produced $34 \%$ higher sulforaphane content, but as a result of the high deviation at $P=0.05$ level, the difference was not significant. The sulforaphane content of main

florets in the fall harvest was considerably greater than in the spring-harvested florets. This was possibly partly the result of the changes in air temperature, the low, near freezing temperatures measured during the development of the florets. Under optimal water supply the sulforaphane content of the fall-harvested broccoli main florets was threefold higher than in those harvested on 24 June. The sulfur treatment under optimal water supply or water deficit increased the sulforaphane content (by $14 \%$ and $15 \%$, respectively) but this increase was not significant. The side florets were harvested on 28 Oct. and a great increase in sulforaphane content was measured compared with the first fall harvest (main florets). In this experiment the sulforaphane content of the side florets was double the values in the main florets and was significantly higher in all treatments.

Foliar sulfur treatment combined with irrigation resulted in the only significant

Table 1. Average yield (t.ha $\left.{ }^{-1}\right)$ of broccoli in the different treatment variations in spring and fall season of 2010

\begin{tabular}{lccrc}
\hline Treatments & Spring total & Fall first harvest & Fall last harvest & Fall total \\
\hline Irrigated & $9.2 \pm 0.77$ & $6.4 \pm 2.07 \mathrm{ab}$ & $13.2 \pm 1.29 \mathrm{a}$ & $19.6 \pm 2.39$ \\
Irrigated + sulfur & $9.8 \pm 2.2$ & $11.7 \pm 4.58 \mathrm{~b}$ & $8.4 \pm 5.54 \mathrm{~b}$ & $20.1 \pm 3.81$ \\
Unirrigated & $4.7 \pm 2.91 \mathrm{a}$ & $12.7 \pm 0.22 \mathrm{a}$ & $17.4 \pm 3.06$ \\
Unirrigated + sulfur & & $6 \pm 1.5 \mathrm{ab}$ & $12.4 \pm 1.61 \mathrm{a}$ & $18.4 \pm 2.49$ \\
\hline
\end{tabular}

Data in the same column bearing the same letter are not significant at $P=0.05$.

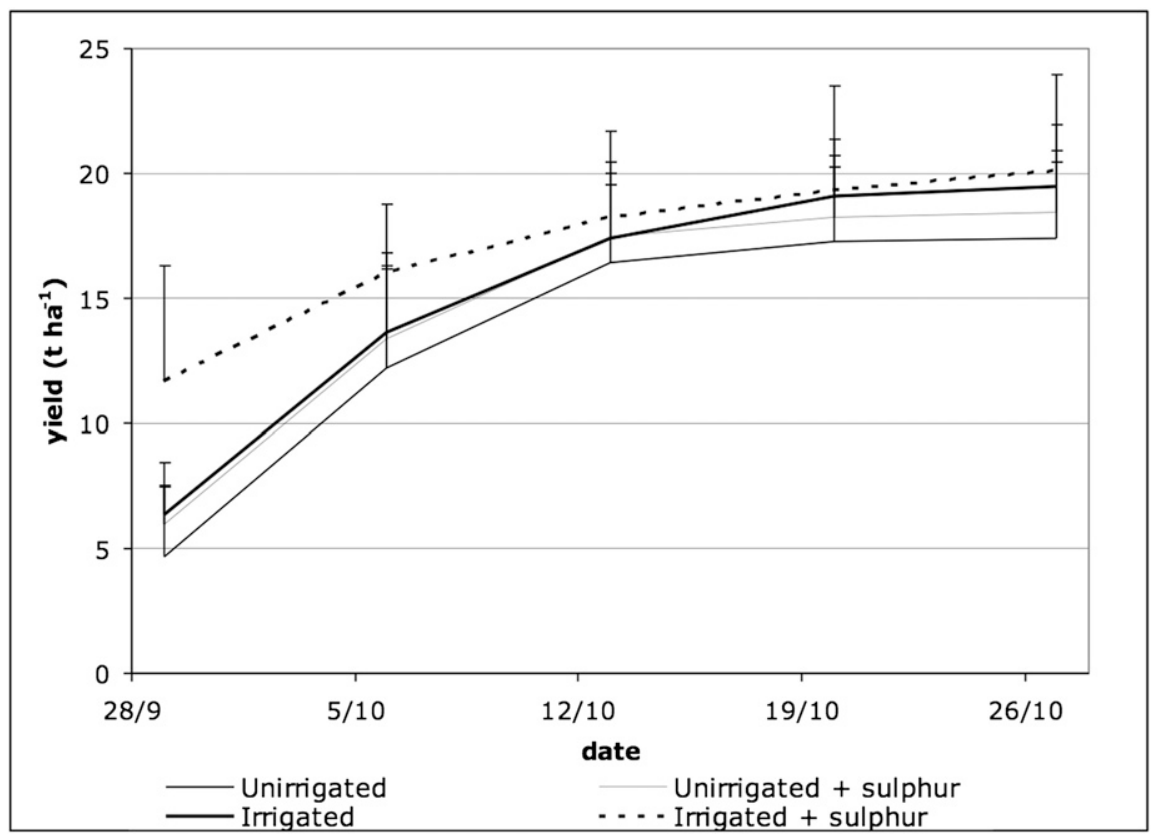

Fig. 3. Accumulated yield of broccoli in the different treatment variations in the fall season of $2010(n=3)$.

Table 2. Average sulforaphane content $\left(\mathrm{mg} \cdot \mathrm{kg}^{-1}\right)$ in the different treatment combinations in spring and fall seasons of $2010(n=3)$.

\begin{tabular}{lccc}
\hline Treatments & Spring total & Fall first harvest & Fall last harvest \\
\hline Irrigated & $9.9 \pm 2.5 \mathrm{aA}$ & $32.2 \pm 5.1 \mathrm{aB}$ & $84.1 \pm 13.6 \mathrm{bC}$ \\
Irrigated + sulfur & $13.3 \pm 1.7 \mathrm{aA}$ & $36.7 \pm 6.0 \mathrm{abB}$ & $60.5 \pm 6.7 \mathrm{aC}$ \\
Unirrigated & & $41.7 \pm 8.6 \mathrm{abA}$ & $93.1 \pm 15.2 \mathrm{bB}$ \\
Unirrigated + sulfur & & $48.0 \pm 10.6 \mathrm{bA}$ & $99.9 \pm 29.1 \mathrm{bB}$ \\
\hline
\end{tabular}

Data in the same column bearing the same small letter, in the same row bearing the same capital are not significant at $P=0.05$. 
decrease in sulforaphane content in the last harvest (side florets) of the fall season.

Because of the pattern of measured sulforaphane content in the fall, we tried to find a correlation between air temperature and this phytochemical. Among average daily minimum, mean, and maximum air temperature, as independent variables, and sulforaphane content as the dependent variable, the regression functions were calculated during curd development (16 d) (Fig. 4). Best fit of curves was given by power function, and the three regression curves did not differ significantly. The lower the air temperature values, the higher the sulforaphane content.

Total phenols. Harvest date had an influence on total polyphenol content with the highest values measured in spring, but we did not find a significant difference between irrigated and rainfed treatments compared with fall harvests. Sulfur treatment combined with irrigation increased total polyphenol content (by $24 \%$ ) in spring but not in the fall compared with irrigation treatment alone (Table 3). Like total phenol compounds, harvest date
Trolox equivalent antioxidant capacity.

affected TEAC values. Also the highest values $\left(4.3 \mathrm{mmol} \cdot \mathrm{kg}^{-1}\right)$ were measured in spring, but the difference was not significant between unirrigated and irrigated treatments when compared with fall harvests. When comparing the effect of harvest date in irrigated treatment alone or irrigation treatment combined with sulfur treatment, there was a significant difference between spring and fall season harvests in their antioxidant activity. In both irrigated and irrigated + sulfur treatments, in spring harvest, TEAC values were significantly higher by $24 \%$ and $11 \%$, respectively (Table 3 ).

Phenolic composition. Table 4 shows composition of phenols from the main florets. The HPLC analysis revealed the occurrence of different polymers of sinapic and ferulic acid in broccoli florets as major phenolic compounds followed by caffeic acid glucoside (Table 4). Its content was not significantly different in spring harvest as compared with fall harvest broccoli main florets, except for the irrigated plus sulfur treatment in which its level was significantly lower by $30 \%$ to $40 \%$ as compared with other treatments.

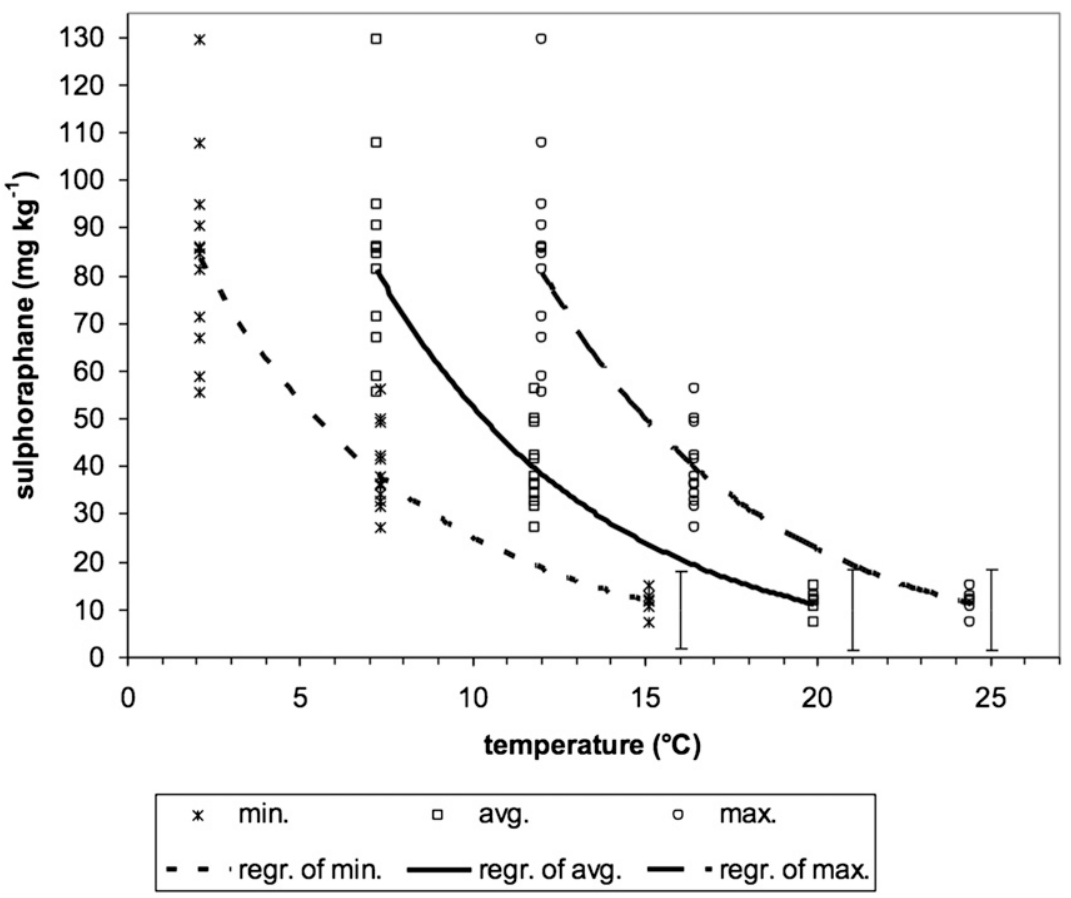

Fig. 4. Correlation among average daily temperature of minimum, mean, and maximum and sulforaphane content during the curd development period. Vertical bars represent SE of regressions $(n=30$; minimum: $\mathrm{y}=114.71 \mathrm{e}^{-0.1518 \mathrm{x}}, R^{2}=0.9169$; avg.: $\mathrm{y}=239.21 \mathrm{e}^{-0.1521 \mathrm{x}}, R^{2}=0.9176$; maximum: $\mathrm{y}=$ $\left.547.94 \mathrm{e}^{-0.1596 x}, R^{2}=0.9167\right)$.

Table 3. Average total phenolics content and TEAC in the different treatment combinations in spring and fall seasons of $2010(n=3)$.

\begin{tabular}{lcccc}
\hline Treatments & $\begin{array}{c}\text { Total phenolics } \\
\text { spring }\left(\mathrm{mg} \cdot \mathrm{kg}^{-1}\right)\end{array}$ & $\begin{array}{c}\text { Total phenolics fall } \\
\text { first harvest }\left(\mathrm{mg} \cdot \mathrm{kg}^{-1}\right)\end{array}$ & $\begin{array}{c}\text { TEAC spring } \\
\left(\mathrm{mmol} \cdot \mathrm{kg}^{-1}\right)\end{array}$ & $\begin{array}{c}\text { TEAC fall first } \\
\text { harvest }\left(\mathrm{mmol}^{-\mathrm{kg}^{-1}}\right)\end{array}$ \\
\hline Irrigated & $674.3 \pm 69.4 \mathrm{a}$ & $680 \pm 65.7$ & $4.3 \pm 0.3$ & $3.4 \pm 0.3$ \\
Irrigated + sulfur & $838.3 \pm 57.9 \mathrm{~b}$ & $736 \pm 4.1$ & $3.9 \pm 0.1$ & $3.5 \pm 0.1$ \\
Unirrigated & $770.3 \pm 58.0$ & & $3.8 \pm 0.5$ \\
Unirrigated + sulfur & & $775 \pm 96.4$ & & $3.7 \pm 0.2$ \\
\hline
\end{tabular}

Data in the same column bearing the same letter are not significant at $P=0.05$.

$\mathrm{TEAC}=$ trolox equivalent antioxidant capacity.
However, its content was significantly higher in fall side florets (by $15 \%$ to $100 \%$ ) as compared with that found in spring or fall main florets. It was found that the seasonal variation had no significant effects on the level of apigenine derivative, gallic acid, and chlorogenic acid. An exception for this is the $89 \%$ to $91 \%$ decrease in the fall rainfed treatment in main florets for the chlorogenic acid. This dramatic decrease needs more studies to be explained. Sinapic acid glucoside content was higher in all the fall season treatments (three- to sixfold) compared with the spring season, but it was lower by $25 \%$ to $33 \%$ in the irrigated plus foliar sulfur supplementation treatment in main florets.

Kaempferol-diglucoside content was lower in all the fall treatments, especially in the irrigated treatments in main florets, in which its value was reduced by $63 \%$ to $79 \%$ and in side florets of the rainfed treatment by $87 \%$ to $94 \%$. The same fall trend was observed in total sinapic-ferulic acid polymer and total sinapic acid polymer content, in which values in the irrigated fall treatments were lower by $69 \%$ to $86 \%$ and $17 \%$ to $62 \%$, respectively, in main florets. Ferrulic acid content was unaffected either by harvest time or by other treatments. However, ferrulic acid polymer was higher in all the fall treatments with highest values measured in fall main florets (10- to 20-fold) as compared with values obtained in spring. Gallic acid was the only phenolic component that was significantly increased by foliar sulfur treatments in both spring and fall seasons and in irrigated or rainfed treatments with maximum values in the fall-irrigated plus sulfur treatment in both main and side florets (Table 4).

\section{Discussion}

As a result of the near optimal precipitation during the spring season, there was no significant difference in yield between the irrigated and nonirrigated treatments. Yield was significantly higher in the fall harvests but also no significant effect of irrigation could be established. Foliar sulfur treatment significantly induced earliness in irrigated broccoli at the first harvest date by $44 \%$, which has not been reported by previous articles.

Sulforaphane content was higher in the fall harvests compared with spring harvest, regardless of treatment, which is in agreement with the findings of previous reports (Charron et al., 2005a; Rosa and Rodrigues, 2001). Foliar sulfur treatment increased sulforaphane content in the first main rosette harvest of fall and spring seasons, but the change was not statistically significant. Foliar sulfur treatment combined with irrigation significantly decreased sulforaphane content in the last harvest (side florets) of fall. Rangkadilok et al. (2004) investigated the effect of sulfur fertilizer on glucoraphanin levels in broccoli at different growth stages and the gypsum applications during the early vegetative phase of the three broccoli cultivars increased sulfur (S) uptake and the 


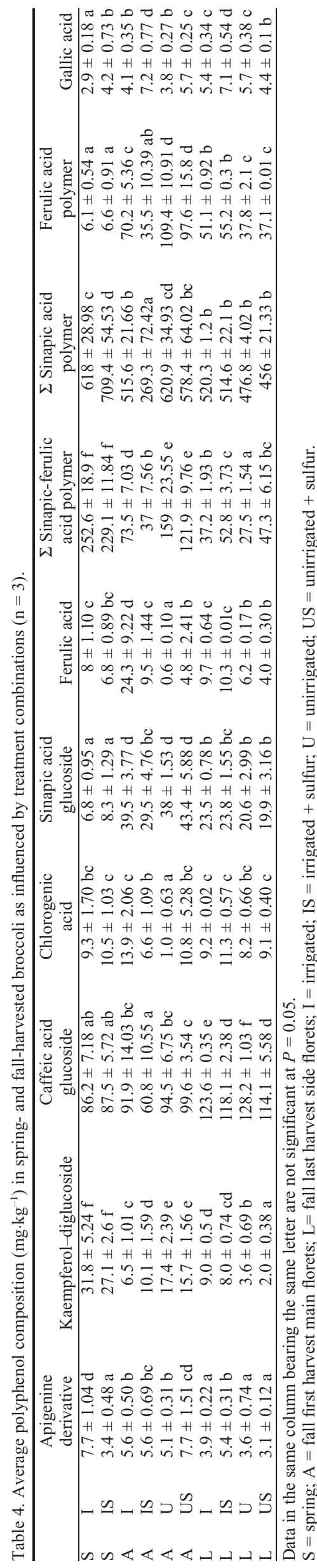

glucoraphanin content in each plant organ. Sulfur present in glucoraphanin accounted for only $4 \%$ to $10 \%$ of total $\mathrm{S}$ content in broccoli heads. They found that the partitioning of $\mathrm{S}$ into glucoraphanin also increased with gypsum applications. Schonhof et al. (2007) studied how S and nitrogen (N) supply influenced growth, product appearance, and glucosinolate concentration of broccoli. According to their results, the total glucosinolate concentrations were high with insufficient $\mathrm{N}$ supply, independent of the S level, and low with insufficient $\mathrm{S}$ supply in combination with an optimal $\mathrm{N}$ supply.

Robbins et al. (2005) studied the effect of cultivation conditions and selenium fertilization on the phenolic profile and sulforaphane content of broccoli. They found that there was no detectable pattern that suggested that water treatment or farming method had a greater influence on phenolic production. Furthermore, their results showed that the production method affected glucosinolate content, because both water stress and organic farming decreased glucosinolate content relative to unstressed, conventionally grown broccoli.

Harvest season influenced total phenolic content as reported by Aires et al. (2011), Aldrich et al. (2011), and Koh et al. (2009). The highest values were measured in the spring season. Sulfur treatment in combination with irrigation increased total phenolic content by $24 \%$ in spring.

Harvest season also affected TEAC values similar to the findings of Aires et al. (2011). The highest values $\left(4.3 \mathrm{mmol} \cdot \mathrm{kg}^{-1}\right)$ were also measured in spring. In the irrigated treatment alone or irrigated treatment combined with $\mathrm{S}$ treatment, spring season values were significantly higher by $24 \%$ and $11 \%$, respectively, compared with fall values. Seasonal effect and S supplementation (soil not foliar application) related changes in certain phenolic compound contents, which has only been reported by Vallejo et al. (2003b) for broccoli under early and late spring climatic conditions in Spain, not comparable to our spring and fall climatic data. The positive effect of $\mathrm{S}$ supplementation on gallic acid content could be expected according to Cartea et al. (2011). Gallic acid was the only phenolic component, the content of which was significantly increased by foliar $\mathrm{S}$ treatments regardless of season or irrigation with maximum values in the fall irrigated plus $\mathrm{S}$ treatment.

\section{Literature Cited}

Aires, A., C. Fernandes, R. Carvalho, R.N. Bennett, M.J. Saavedra, and E.A.S. Rosa. 2011. Seasonal effects on bioactive compounds and antioxidant capacity of six economically important Brassica vegetables. Molecules 16:6816-6832.

Aldrich, H.T., P. Kendall, M. Bunning, F. Stonaker, O. Kulen, and C. Stushnoff. 2011. Environmental temperatures influence antioxidant properties and mineral content in broccoli cultivars grown organically and conventionally. J. Agron. Crop Sci. 2:1-10

Anupama, M., S.S. Murgan, and P. Balakrishna Murthy. 2008. Broccoli flower head extract reduces mitomycin-C induced sister chromatid exchange in cultured human lymphocytes. Food Chem. Toxicol. 46:3351-3353.

Brand-Williams, W., M.E. Cuvelier, and C. Berset. 1995. Use of a free radical method to evaluate antioxidant activity. LWT-Food Sci. Technol. 28:25-30.

Brown, A.F., G.G. Yousef, E.H. Jeffery, B.P Klein, M.A. Wallig, M.M. Kushad, and J.A Juvik. 2002. Glucosinolate profiles in broccoli: Variation in levels and implications in breeding for cancer chemoprotection. J. Amer. Soc. Hort. Sci. 127:807-813.

Cartea, M.E., M. Francisco, P. Soengas, and P. Velasco. 2011. Phenolic compounds in Brassica vegetables. Molecules 16:251-280.

Charron, C.S., A.M. Saxton, and C.E. Sams. 2005a. Relationship of climate and genotype to seasonal variation in the glucosinolate-myrosinase system. I. Glucosinolate content in ten cultivars of Brassica oleracea grown in fall and spring seasons. J. Sci. Food Agr. 85:671-681.

Charron, C.S., A.M. Saxton, and C.E. Sams. 2005b. Relationship of climate and genotype to seasonal variation in the glucosinolate-myrosinase system. II. Myrosinase activity in ten cultivars of Brassica oleracea grown in fall and spring seasons. J. Sci. Food Agr. 85:682-690.

Clarke, J.D., R.H. Dashwood, and E. Ho. 2008 Multi-targeted prevention of cancer by sulforaphane. Cancer Lett. 269:291-304

Cogo, S.L.P., F.C. Chaves, M.A. Schirmer, R.C Zambiazi, L. Nora, J.A. Silva, and C.V. Rombaldi. 2011. Low soil water content during growth contributes to preservation of green colour and bioactive compounds of cold-stored broccoli (Brassica oleraceae L.) florets. Postharvest Biol. Technol. 60:158-163.

Conaway, C.C., S.M. Getahun, L.L. Liebes, D.J Pusateri, D.K.W. Topham, M. Botero-Omary, and F.-L. Chung. 2000. Disposition of glucosinolates and sulforaphane in humans after ingestion of steamed and fresh broccoli. Nutr. Cancer 38:168-178.

Dinkova-Kostova, A.T., S.N. Jenkins, J.W. Fahey, L. Ye, S.L. Wehage, K.T. Liby, K.K. Stephenson, K.L. Wade, and P. Talalay. 2006. Protection against UV-light-induced skin carcinogenesis in SKH-1 high-risk mice by sulforaphane-containing broccoli sprout extracts. Cancer Lett. 240(2): 243-252.

Gills, J.J., E.H. Jeffery, N.V. Matusheski, R.C. Moon, D.D. Lantvit, and J.M. Pezzuto. 2006. Sulforaphane prevents mouse skin tumorigenesis during the stage of promotion. Cancer Lett. 236:72-79.

Gliszczyńska-Świgło, A., A. Kałuzewicz, K. Lemańska, M. Knaflewski, and B. Tyrakowska. 2007. The effect of solar radiation on the flavonol content in broccoli inflorescence. Food Chem. 100:241-245.

Guerrero-Beltrán, C.E., M. Calderón-Oliver, J. Pedraza-Chaverri, and Y.I. Chirino. 2012a Protective effect of sulforaphane against oxidative stress: Recent advances. Exp. Toxicol. Pathol. 64:503-508.

Guerrero-Beltrán, C.E., P. Mukhopadhyay, B Horváth, M. Rajesh, E. Tapia, I. García-Torres, J. Pedraza-Chaverri, and P. Pacher. 2012b. Sulforaphane, a natural constituent of broccoli, prevents cell death and inflammation in nephropathy. J. Nutr. Biochem. 23:494-500.

Helyes, L. and G. Varga. 1994. Irrigation demand of tomato according to the results of three decades. Acta Hort. 376:323-328.

Herr, I. and M.W. Büchler. 2010. Dietary constituents of broccoli and other cruciferous vegetables: Implications for prevention and therapy of cancer. Cancer Treat. Rev. 36:377-383. 
Hungarian Meteorological Service. 2010. Weather forecast. <http://www.met.hu/idojaras/elorejelzes/>.

Jahangir, M., I.B. Abdel-Farid, H.K. Kim, Y.H. Choi, and R. Verpoorte. 2009. Healthy and unhealthy plants: The effect of stress on the metabolism of Brassicaceae. Environ. Exp. Bot. 67:23-33.

Jeffery, E.H., A.F. Brown, A.C. Kurilich, A.S. Keck, N. Matusheski, B.P. Klein, and J.A. Juvik. 2003. Variation in content of bioactive components in broccoli. J. Food Compost. Anal. 16:323-330.

Koh, E., K.M.S. Wimalasiri, A.W. Chassy, and A.E. Mitchell. 2009. Content of ascorbic acid, quercetin, kaempferol and total phenolics in commercial broccoli. J. Food Compost. Anal. 22(7-8):637-643.

Liang, H., Q.P. Yuan, H.R. Dong, and Y.M. Liu. 2006. Determination of sulforaphane in broccoli and cabbage by high-performance liquid chromatography. J. Food Compost. Anal. 19:473-476.

MSZ 9474. 1980. Borok polifenoltartalmának meghatározása [Wines. Determination of polyphenol content].

Nakagawa, K., T. Umeda, O. Higuchi, T. Tsuzuki, T. Suzuki, and T. Miyazawa. 2006. Evaporative light-scattering analysis of sulforaphane in broccoli samples: Quality of broccoli products regarding sulforaphane contents. J. Agr. Food Chem. 54:2479-2483.
Pérez-Balibrea, S., D.A. Moreno, and C. GarcíaViguera. 2011. Genotypic effects on the phytochemical quality of seeds and sprouts from commercial broccoli cultivars. Food Chem. 125:348-354.

Podsedek, A. 2007. Natural antioxidants and antioxidant capacity of Brassica vegetables: A review. LWT-Food Sci. Technol. 40:1-11.

Rangkadilok, N., M.E. Nicolas, R.N. Bennett, D.R. Eagling, R.R. Premier, and J. Taylor. 2004. The effect of sulfur fertilizer on glucoraphanin levels in broccoli (B. oleracea L. var. italica) at different growth stages. J. Agr. Food Chem. 52:2632-2639.

Robbins, R.J., A.S. Keck, G. Banuelos, and J.W Finley. 2005. Cultivation conditions and selenium fertilization alter the phenolic profile, glucosinolate, and sulforaphane content of broccoli. J. Med. Food 8:204-214.

Rosa, E.A.S. and A.S. Rodrigues. 2001. Total and individual glucosinolate content in 11 broccoli cultivars grown in early and late seasons. HortScience 36:56-59.

Sakata Vegetables Europe, S.A.S. 2012. Parthenon F1. <http://www.sakata-eu.com/vegetables/ product_veg.asp? CategoryId $=7 \&$ SpeciesId $=2 \&$ VarietyId $=189>$.

Schonhof, I., D. Blankenburg, S. Müller, and A. Krumbein. 2007. Sulfur and nitrogen supply influence growth, product appearance, and glucosinolate concentration of broccoli. J. Plant Nutr. Soil Sci. 170:65-72.

Tomás-Barberán, F.A. and J.C. Espín. 2001. Phenolic compounds and related enzymes as determinants of quality in fruits and vegetables. J. Sci. Food Agr. 81:853-876.

Vallejo, F., C. García-Viguera, and F.A. TomásBarberán. 2003a. Changes in Broccoli (Brassica oleracea L. Var. italica) health-promoting compounds with inflorescence development. J. Agr. Food Chem. 51:3776-3782.

Vallejo, F., F.A. Tomás-Barberán, and C. GarcíaViguera. 2003b. Effect of climatic and sulfur fertilisation conditions, on phenolic compounds and vitamin $\mathrm{C}$, in the inflorescences of eight broccoli cultivars. Eur. Food Res. Technol. 216:395-401.

Vallejo, F., F.A. Tomás-Barberán, A. Gonzalez Benavente-García, and C. García-Viguera. 2003c. Total and individual glucosinolate contents in inflorescences of eight broccoli cultivars grown under various climatic and fertilisation conditions. J. Sci. Food Agr. 83:307-313.

Vallejo, F., F.A. Tomás-Barberán, and C. GarciaViguera. 2002. Glucosinolates and vitamin C content in edible parts of broccoli florets after domestic cooking. Eur. Food Res. Technol. 215:310-316. 